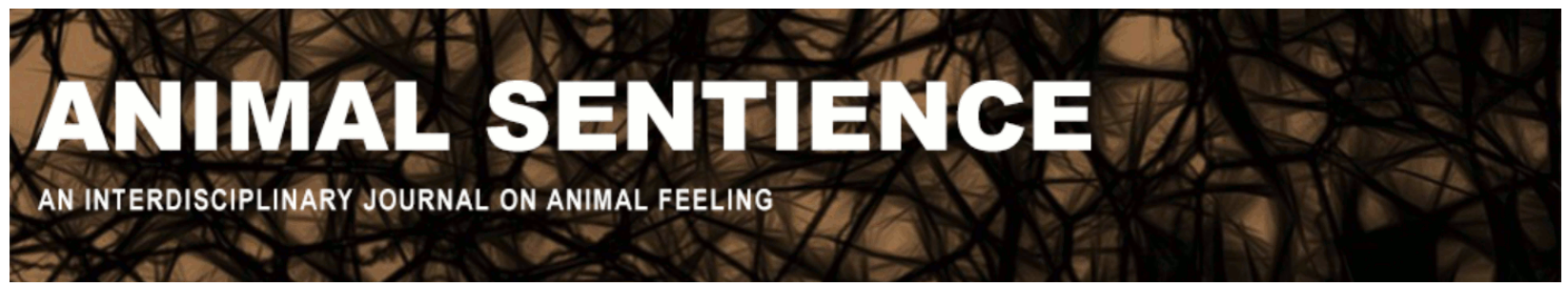

Rollin, Bernard (2018) Human superiority?. Animal Sentience 23(5)

DOI: $10.51291 / 2377-7478.1384$

Date of submission: 2019-01-26

Date of acceptance: 2019-01-31

(c) (i)

This article has appeared in the journal Animal

Sentience, a peer-reviewed journal on animal

cognition and feeling. It has been made open access,

free for all, by WellBeing International and deposited

in the WBI Studies Repository. For more information,

please contact

wbisr-info@wellbeingintl.org.

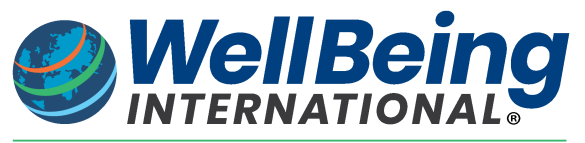

SOLUTIONS FOR PEOPLE, ANIMALS AND ENVIRONMENT 


\title{
Human superiority?
}

Commentary on Chapman \& Huffman on Human Difference

\author{
Bernard Rollin \\ Department of Philosophy \\ Colorado State University
}

\begin{abstract}
Like Charles Darwin and George Romanes, I am quite willing to use anecdotal information as a source of knowledge about animal behavior. There are many more people observing nonhuman animals than there are people conducting controlled experiments, and we can thereby learn that behaviors we think are unique to humans are shared by other animals. From a strictly biological point of view, it makes no sense to speak of "human superiority." One species of animal can be superior to another only in terms of survival and niche occupation. As moral concern for animals increases across the world, claims of human superiority tend to disappear.
\end{abstract}

Bernard Rollin is Distinguished Professor of Philosophy, Animal Sciences and Biomedical Sciences, at Colorado State University. One of the leading scholars in animal rights and animal consciousness, he has lectured worldwide. Website

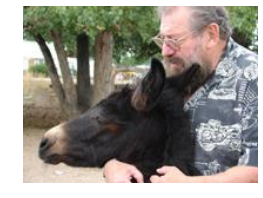

I have taught in universities for well over four decades. One of my major pursuits in both writing and teaching is animal ethics. Virtually every time I teach such a class, I encounter the same objection from some students: "Why do you waste your time on animal issues when there are so many human ethical issues requiring resolution?" Fortunately, many of the students are far too intelligent to be taken in by such an approach. One woman who grew up on a very rural ranch, in response to this objection, snapped "morality is not a single shot shotgun!" Last semester I was asked much the same question.

This time, I tried a different tactic. I asked the students how many of them had ever been betrayed by a friend. Every hand went up. I then asked them how many of them had been betrayed by a lover. Again, every hand was raised. Finally, I asked them how many had been betrayed by a family member, and again every hand went up. Next, I asked them how many of them had ever been betrayed by an animal, and not a single hand was raised. I pointed out that here was an excellent justification for devoting my attention to animals - that plus the fact that animals are innocent and rarely if ever do anything evil.

I am not averse to relying on anecdotal information as a source of knowledge about animal behavior. Most of our knowledge of human behavior is in fact derived that way - very little comes from "scientific psychology." Both Charles Darwin and his colleague George Romanes combed through endless anecdotes looking for replication in instances of animal behavior. As Chapman \& Huffman (2018) remark, there are many traits alleged to be found only among humans that are in fact present throughout the animal community, ranging from numerical concepts to altruistic behavior even among rats. 
It has often been pointed out that from the point of view of evolutionary theory, it makes no sense to talk about species superiority. If a type of animal survives, flourishes, and establishes itself in many niches, we can say with confidence that it is superior to others suffering extinction. If that is the case, we are inferior to the cockroach, an organism that occupies at least as many environments as we do; has been around longer; and will allegedly survive a nuclear holocaust!

Perhaps human superiority makes sense in a theological context, where elaborate edifices are constructed to justify such a claim. But in secular contexts, there is no way to justify claims of general superiority in comparison to other organisms. My dog is considerably faster than I am, my cat is a better hunter, a squirrel is a more accomplished acrobat, a tadpole is a better swimmer, etc., across the whole range of animals.

Even in moral terms, we are hard-pressed to claim superiority. Rarely do we find human friends who are as loyal as one's dog. We have all witnessed the news stories depicting great apes saving babies who have fallen into an enclosure at a zoo. And consistent research indicates that even rats will refuse treats if their price is the suffering of another rat. We can rarely if ever label an animal evil or sadistic.

Claims of human superiority are self-serving. If we are superior in force to other animals, we can eat them, experiment on them, essentially enslave them in any ways we choose. If we are indeed morally superior, the last thing we should do is act according to "might makes right," a principle that morality has been in good part developed to confute!

In sum, Chapman \& Huffman are right to call attention to the vacuity of the claim that humans are superior to animals. And this is a particularly good time to bring forward such an assertion. All around the world, there are movements to grant legal status of some partial sort to animals, from the Swedish law of 1989 for agricultural animals granting to cattle in perpetuity the right to graze, to people arguing that habeas corpus should be extended to nonhuman animals. (I was part of a group of 17 philosophers who argued this point as an appeal to a New York State Court, claiming that two chimps were being deprived of adequate living conditions. Though we adduced many sophisticated arguments, the judges held, in a classic piece of circular reasoning, that habeas corpus only applies to humans.) Responding to societal pressure, the NIH has ordered that no biomedical research be done on Great Apes. In an increasing number of states, courts deciding where companion animals are to live after divorce proceedings are now mandated to consider the best interests of the animal. There has been more legislation pertaining to animal welfare during the last 50 years than in the previous 500 . All of this bodes well for putting to rest arbitrary claims of human superiority.

\section{References}

Chapman, C. A. and Huffman, M. A. (2018) Why do we want to think humans are different? Animal Sentience 23(1)

Darwin, C. (1871) The Descent of Man and Selection in Relation to Sex. New York: Modern Library Darwin, C. (1872/1969) The Expression of the Emotions in Man and Animals. New York: Greenwood Press Romanes, G. (1884) Mental Evolution in Animals. New York: Appleton

Romanes, G. (1898) Animal Intelligence. London: Kegan Paul, Trench, Trubner and Co. 